\title{
The Role of VEGF in Oncology: Effects on Hemostasis and Thrombosis
}

\author{
Herbert M. Pinedo \\ Department of Medical Oncology, VUMC, Amsterdam, The Netherlands
}

Angiogenesis is essential for tumor growth and metastasis [1]. One of the key players in the angiogenic process is vascular endothelial cell growth factor (VEGF), which exerts its effects through in particular VEGFR-1 (Flt-1 murine homologue) and VEGFR-2 (KDR human homologue; Flk-1 murine homologue) located on endothelial cells (ECs) [2]. These well known effects include increased permeability, proliferation and migration of ECs. However, VEGF also affects hemostatic properties of ECs by inducing the rapid release of von Willebrand factor (vWF), by increasing the expression of tissue factor (TF) and thrombomodulin (TM), and by modifying fibrinolysis due to the stimulation of the expression levels of tissue-plasminogen activator (t-PA), urokinase-plasminogen activator (u-PA), plasminogen activator inhibitor-1 (PAI-1) and the receptor for u-PA (u-PAR) [3-13]. VEGF stimulated ECs furthermore promote adhesion and activation of platelets [9]. On the other hand, platelets are transporters of among other factors VEGF and have most likely a role in tumor induced angiogenesis $[14,15]$. This hypothesis has been confirmed by the finding of very high concentrations of both VEGF and coagulation factors in tumor fluid of soft tissue sarcomas [16]. There is growing evidence that coagulation, platelets and angiogenesis are indistinguishable involved in tumor growth.

\section{References}

1 Hanahan D, Folkman J: Patterns and emerging mechanisms of the angiogenic switch during tumorigenesis. Cell 1996;86:353-364.

2 Carmeliet P, Jain RK: Angiogenesis in cancer and other diseases. Nature 2000;407:249-257.

3 Li W, Keller G: VEGF nuclear accumulation correlates with phenotypical changes in endothelial cells. J Cell Sci 2000;113:1525-1534.
4 Brock TA, Dvorak HF, Senger DR: Tumorsecreted vascular permeability factor increases cytosolic $\mathrm{Ca}^{2+}$ and von Willebrand factor release in human endothelial cells. Am J Pathol 1991;138: 213-221.

5 Zanetta L, Marcus SG, Vasile J, et al: Expression of von Willebrand factor, an endothelial cell marker, is up-regulated by angiogenesis factors: A potential method for objective assessment of tumor angiogenesis. Int J Cancer 2000;85:281-288.
6 Clauss M, Gerlach M, Gerlach H, et al: Vascular permeability factor: A tumor-derived polypeptide that induces endothelial cell and monocyte procoagulant activity, and promotes monocyte migration. J Exp Med 1990;172:1535-1545.

7 Camera M, Giesen PLA, Fallon J, et al: Cooperation between VEGF and TNF- $\alpha$ is necessary for exposure of active tissue factor on the surface of human endothelial cells. Arterioscler Thromb Vasc Biol 1999;19:531-537.

\begin{tabular}{ll}
\hline KARGER & ( ) 2003 S. Karger AG, Basel \\
1424-8832/03/0337-0011\$19.50/0 \\
$\begin{array}{l}\text { Fax +4161306 1234 } \\
\text { E-Mail karger@karger.ch } \\
\text { www.karger.com }\end{array}$ & $\begin{array}{l}\text { Accessible online at: } \\
\text { www.karger.com/journals/pht }\end{array}$
\end{tabular}

Fax +4161306 1234
E-Mail karger@karger.c www.karger.com Accessible online at:
www.karger.com/journals/pht
Herbert M. Pinedo

Department of Medical Oncology, VUMC

P.O. Box 7057 Amsterdam (The Netherlands)

Tel. +3120 4444303, Fax +3120 4444081, E-Mail hm.pinedo@azvu.nl 
8 Mechtcheriakova D, Wlachos A, Holzmuller H, et al: Vascular endothelial cell growth factorinduced tissue factor expression in endothelial cells is mediated by EGR-1. Blood 1999;93:3811-3823.

9 Verheul HM, Jorna AS, Hoekman K, et al: Vascular endothelial growth factor-stimulated endothelial cells promote adhesion and activation of platelets. Blood 2000;96:4216-4221.

10 Calnek DS, Grinnell BW: Thrombomodulindependent anticoagulant activity is regulated by vascular endothelial growth factor. Exp Cell Res 1998;238:294-298.

11 Pepper MS, Ferrara N, Orci L, et al: Vascular endothelial growth factor (VEGF) induces plasminogen activators and plasminogen activator inhibitor-1 in microvascular endothelial cells. Biochem Biophys Res Commun 1991;181: 902-906.
12 Mandriota SJ, Pepper MS: Vascular endothelial growth factor-induced in vitro angiogenesis and plasminogen activator expression are dependent on endogenous basic fibroblast growth factor. J Cell Sci 1997;110:2293-2302.

13 Kroon ME, Koolwijk P, Vermeer MA, et al: Vascular endothelial growth factor enhances the expression of urokinase receptor in human endothelial cells via protein kinase $\mathrm{C}$ activation. Thromb Haemost 2001;85:296-302.

14 Verheul HM, Hoekman K, Luykx-de Bakker S, et al: Platelet: Transporter of vascular endothelial growth factor. Clin Cancer Res 1997;3:2187-2190.
15 Pinedo HM, Verheul HM, D'Amato RJ, et al: Involvement of platelets in tumour angiogenesis? Lancet 1998;352:1775-1777.

16 Verheul HM, Hoekman K, Lupu F, et al: Platelet and coagulation activation with vascular endothelial growth factor generation in soft tissue sarcomas. Clin Cancer Res 2000;6:166-171. 